\title{
THE INFLUENCE OF CHOSEN STATISTICAL METHODS OF DETECTING OUTLIERS ON PROPERTY VALUATION RESULT
}

\author{
Anna Barańska \\ Departament of Integrated Geodesy and Cartography \\ AGH University of Science and Technology \\ e-mail:abaran@agh.edu.pl \\ Beata Śpiewak \\ Departament of Integrated Geodesy and Cartography \\ AGH University of Science and Technology \\ e-mail: spiewak@agh.edu.pl
}

\begin{abstract}
The subject of the thesis concerns the application of selected statistical methods searching for outliers in the process of determining the value of real estate, based on a functional model adjusted to market data.

The collected research material consisted of data on land properties, which were the subject of transactions on local markets, for which there was no information regarding the specific conditions of concluding the sale agreement. After the initial selection of data regarding the purpose of the property in the local plan, the type of property rights being sold and the size of the shares sold - a functional model was adjusted to the obtained data, showing the relationship between the price being the dependent variable and the features of the property being the independent variables. Then, two statistical methods of searching for outliers which are significantly different in their algorithms, i.e. Cook's distance and robust estimation method called Pope's method, were applied to each model. The last stage was to determine the model values of selected properties and to compare the obtained results with the known transaction prices of the parcels being the subject of the valuation.

The conducted research allowed for the verification of the influence of significantly different statistical methods searching for outliers on the property valuation result and its accuracy.
\end{abstract}

Keywords: Cook's distance, Pope's method, property valuation, mulivariate linear model, mulivariate nonlinear model.

JEL Classification: C10, C51, R22.

Citation: Barańska, A. \& Śpiewak, B. (2021). The influence of chosen statistical methods of detecting outliers on property valuation result. Real Estate Management and Valuation, 29(1), 87-97.

DOI: https://doi.org/10.2478/remav-2021-0008

\section{Introduction}

Real estate appraisal is a process as a result of which the real estate value is determined by a real estate appraiser. The law defines the types of values that the appraiser can determine, but also the approaches, methods and techniques that should be used depending on, inter alia, the purpose of the valuation, the individual characteristics of the property and available information on the real estate market.

The method of statistical analysis of the market (MASR) is one of the methods of real estate valuation within the comparative approach, which uses algorithms for statistical analyses, including 


\section{S sciendo}

mathematical modeling of the market under study. In the case of property valuation, based on a set of representative properties, multidimensional linear and non-linear models seem to be appropriate, in which the dependent variable is the value of the valued property and the attributes are explanatory variables.

In the valuation of real estate using a comparative approach, it is assumed that the value of the real estate corresponds to the prices obtained for similar properties that were traded on the market. Statistical methods searching for outliers can be helpful in the credible modeling of the real estate market. Such methods include, for example, Cook's distance and Pope's robust estimation method. By using the methods of detecting outliers, we usually obtain an improvement in the quality of the functional model, which gives a premise for a more accurate property valuation result, reflecting the real situation in the field of prices obtained for the real estate sold in the market under study.

The article compares the results of the point estimation of the model real estate value obtained after applying Cook's distance and Pope's method to the functional models of a studied real estate market. Then, the obtained results were commented on in relation to transaction prices, which were recorded for the properties, which were the subject of the valuation.

\section{Literature review}

The method of market statistical analysis (MASR) is quite widely described in the scientific literature, both in theoretical and practical terms. In twopublications (Konowalczuk, 2018; Kokot, 2011), the legal conditions for the application of MASR in Poland are presented in detail, referring to the currently applicable provisions of law and judicial decisions. The author of the publication (Zyga, 2014) reviewed the assessments of the admissibility of using MASR in real estate valuation functioning in the literature. On the other hand, the authors of the papers (Sawiłow, 2010; Czaja \& Ligas, 2010) presented the application of MASR to real estate valuation on the basis of numerical examples, in relation to specific real estate markets and types of real estate.

Methods of detecting outliers are the subject of many publications from various fields of science, in which we deal with collecting information and then performing statistical analyses on the obtained data. Among the statistical tools for detecting atypical observations, we can find those methods, whose algorithms require the construction of a functional model adapted to market data. Such methods include Cook's distance (Cook \& Weisberg, 1982; Trzęsiok, 2015; Koronacki \& Mielniczuk, 2001; Hidalgo, et al. 2018; Barros, et al., 2010; Zhu, et al., 2012; Zhao, et al., 2013) and the robust estimation method called Pope's method (Pope, 1961; Prószyński \& Kwaśniak, 2002; Śpiewak, 2018).

\section{Research methodology}

Pope's method and Cook's distance, although different in their construction, both look for observations that differ from the functional model matched to the collected data, so it is necessary to determine the form of this model.

A functional model illustrating the dependencies prevailing on the studied real estate markets, and thus enabling the determination of the model value of a property, may be e.g. a multivariate regression model, described in detail in works (Hormann, 2005; Bittner, 2007; Barańska, 2014; Barańska, 2016; Kokot \& Gnat, 2019) or a multivariate non-linear model (Barańska, 2007, 2008, 2010; Barańska \& Nowak, 2015). For the purposes of this publication, the following models were used:

- additive model in the form of linear multivariate regression:

where:

$$
c=a_{0}+\sum_{i=1}^{m} a_{i} * X_{i}
$$

c - real estate price,

$X_{i} \quad$ - property attributes,

$a_{i} \quad$ - model parameters;

- additive non-linear model, which is the sum of non-linear dependencies $f_{i}$ of the dependent variable on individual explanatory variables $i$, which means a linear combination of explanatory variables transformed according to the components of the $f_{i}$ function model:

$$
c=a_{0}+\sum_{i=1}^{m} f_{i}\left(X_{i}\right)
$$

where:

$f_{i} \quad$ - function of price dependence on $i$-th attribute. 


\subsection{Cook's distance}

Cook's distance is a measure that determines the ratio of the "variance" between the models (with and without the $i$-th case) to the variance of the full model (Koronacki \& Mielniczuk, 2001; Czechowski, et al., 2013), according to the following formula:

$$
D_{i}=\frac{\sum_{j=1}^{n-1}\left(\bar{Y}_{j}-\bar{Y}_{j(i)}\right)^{2}}{u * \widehat{\sigma}_{0}^{2}}
$$

where:

$\bar{Y}_{\mathrm{j}} \quad$ - predicted value of the dependent variable $\mathrm{Y}$ for the observation of $j$ number in the full model, including all cases,

$\bar{Y}_{\mathrm{j}(\mathrm{i})} \quad$ - predicted value of the dependent variable $\mathrm{Y}$ for the observation of $j$ number in the model, built on the set from which the observation of $i$ number was removed,

$u$ - number of the model parameters,

$\hat{\sigma}_{0}^{2} \quad$ - unencumbered estimator of the residual variance, specifying the inaccuracy of the model parameters estimation, taking into account all cases, calculated in accordance with the following formula:

$$
\hat{\sigma}_{0}^{2}=\frac{Y^{T} Y-\hat{a}^{T} Y^{T} Y}{n-u}
$$

where:

$Y \quad$ - vector of the predicted value of the dependent variable $Y$, with dimension $(n \times 1)$,

n - number of all cases,

u - number of model parameters,

$\hat{a}-$ unencumbered estimator of the vector of unknown model parameters, with dimension

$(m \times 1)$, calculated as:

$$
\hat{a}=\left(X^{T} X\right)^{-1} * X^{T} Y
$$

where:

$Y \quad$ - vector of the predicted values of the dependent variable $Y$, with dimension $(n \times 1)$,

$X \quad$ - matrix of variables explaining the model, with dimension $(n \times m)$.

The $i$-th observation is called outlier if its corresponding distance $D_{i}$ is greater than the limit value ( $n$ - number of observations, $u$ - number of model parameters), while scientific literature distinguishes the following limit values: $\frac{4}{n-u-2}$ (Trzęsiok, 2015) or $\frac{4}{n}$ (Czekaj, 2006).

To find outliers, we can rank the obtained results of Cook's distances, considering as outliers those for which the highest $D_{i}$ values were obtained, exceeded the set level. For the purposes of this study, the value of 0.05 was set as the limit value.

\subsection{Pope's method}

Pope's method is among the robust estimation methods. Searching for outliers is done by using a test of individual correction, where the zero hypothesis says: "there are no gross errors in analyzed dataset", against the alternative hypothesis: "there are gross errors in analyzed data set", by the test function having $\tau$ distribution, closely related to the $t$-Student distribution (Kamiński \& Nowel, 1992; Proszyński \& Kwaśniak, 2002; Śpiewak, 2018):

$$
\tau_{i}=\frac{v_{i}}{\sigma\left(v_{i}\right)}=\frac{v_{i}}{\widehat{\sigma}_{0} \sqrt{\left\{I-X\left(X^{\mathrm{T}} X\right)^{-1} X^{\mathrm{T}}\right\}_{\mathrm{ii}}}} \sim \tau(k)
$$

where:

$v_{i} \quad$ - compensatory correction for the $i$-th observation, calculated as the difference between the value of the dependent variable predicted by the model and the observed value of this variable,

$\sigma\left(v_{i}\right)$ - standard deviation of the correction,

$\hat{\sigma}_{0} \quad$ - standard estimation error as the root of the unencumbered estimator of the residual variance, calculated according to the formula (4),

I - identity matrix with dimension $(n \times n)$, 


\section{S sciendo}

$\tau(k) \quad-\tau$ distribution with $k$ degrees of freedom and due to the fact that $\tau$ distribution is not widely known, the creator of the method - Pope, set the relationship between the variables in the $\tau$ distribution and in $t$-Student distribution in the form of Formula (7), enabling the use of the $t$ Student distribution tables:

$$
\tau(k)=\frac{\sqrt{k} \mathrm{t}(k-1)}{\sqrt{k-1+t^{2}(k-1)}}
$$

There are no reasons to reject the zero hypothesis if:

$$
\left|\tau_{i}\right| \leq \tau_{\alpha ; k}
$$

After the detection of one or more observations suspected of being outliers, the further procedure consists of removing cases which do not realize (8), re-estimating the model parameters, examining the significance of model parameter estimators $\hat{a}_{\mathrm{i}}$ and performing a test of individual observation by using statistics (6).

\section{Results of conducted research}

The research material consisted of five data sets containing information about land properties intended for single-family housing, which were traded over a period of three to seven months, in the following towns: Starachowice, Busko-Zdrój, Przeworsk, Proszowice and Kraków (Krowodrza district).

The data about the properties was obtained from the Real Estate Price and Value Register and on the basis of a field inspection.

Due to the same purpose, each property was described with the same following features (ranges of values of individual attributes are given in brackets): transaction date (the number of months from the date of the first transaction in the database, however the transactions came from a relatively short time, which allowed price correction due to time to be ignored), topography (5 - very good, 4 - good, 3 - average, 2 - difficult, 1 - unfavorable), access to public transport (5 - very good; 4 - good, 3 - average, 2 - limited, 1 - bad), surroundings (5 - very favorable, 4 - favorable, 3 - average, 2 - below average, 1 unfavorable), accessibility to public facilities (4 - very good, 3 - good , 2 - average, 1 - bad), location feature expressed by the distance of the property from the city center (5 - very good, 4 - good, 3 average, 2 - distant, 1 - very distant), shape (5 - very favorable, 4 - favorable, 3 - average, 2 inconvenient, 1 - unfavorable), fashion (5 - the most desirable location, 4 - very fashionable location, 3 fashionable location, 2 - moderately fashionable location, 1 - unfashionable location), utilities (4 presence of at least four networks, 3 - presence of three networks, 2 - presence of two networks, 1 presence of one network, 0 - lack of utilities), road type - a feature determined on the basis of the road category and its surface (7 - national road, 6 - voivodeship road, 5 - district road, 4 - hardened communal road, 3 - unpaved communal road, 2 - paved internal road, 1 - unpaved internal road), land area (feature expressed in square meters) and unit price (feature expressed in PLN/ $\mathrm{m}^{2}$ ).

Then, a linear and non-linear multivariate functional model were fitted to each data set, in which the price was the dependent variable of the model and the property features - the independent, explanatory variables. Two methods of detecting observations that deviate from the functional model fitted to the market data, with significantly different algorithms, were used successively: Cook's distance and Pope's method. The last step was to calculate the model values of selected properties for which transaction prices were known, based on a regression model, estimated on the basis of a set of data, without outliers, and to compare the obtained results with the transaction prices of the properties. The results of individual calculations are presented in Tables 1-5.

Table 1a provides information about: property databases collected in time period in which the transactions were concluded, $C_{\text {mean }}$ - mean unit prices of sold properties on local markets, $\sigma_{n-1}-$ unencumbered estimator of dataset standard deviation, $n$ - number of transactions in analyzed part of time, relevant model variables before application of Cook's distance and Pope's method, set on the basis of $t$-Student test, wherein the variables repeated in both models are bolded and $R^{2}-$ determination coefficient before removing outliers. In Table $1 \mathrm{~b}$ there are: $\hat{X}$ - average values of relevant model variables (property attributes), $\sigma_{n-1}$ - unencumbered estimator of standard deviation of property attributes' datasets and $f_{i}(X)$ - function of dependence of price on $i$-th attribute.

The data sets containing information about sold properties, which were the research material in this publication, are characterized by a high value of price variability coefficient, which was calculated as the quotient of the unencumbered estimator of datasets' standard deviation $\sigma_{n-1}$ and average unit 
price of sold properties on the studied market $C_{\text {mean }}$, which can be notice on example of towns such as: Starachowice (0.96), Proszowice (1.22) and Kraków (0.53). For Proszowice, the value of the standard deviation estimator even exceeds the average transaction price.

Table 1a

Databases containing land properties which were subject of transactions

\begin{tabular}{|c|c|c|c|c|c|c|c|c|c|}
\hline \multirow[b]{2}{*}{ Lp. } & \multirow[b]{2}{*}{ Town } & \multirow{2}{*}{$\begin{array}{c}\text { Price } \\
\text { research } \\
\text { period } \\
\text { [number } \\
\text { of months] } \\
\end{array}$} & \multirow[b]{2}{*}{$\begin{array}{c}C_{\text {mean }} \\
{\left[\mathrm{PLN} / \mathrm{m}^{2}\right]}\end{array}$} & \multirow[b]{2}{*}{$\begin{array}{c}\sigma_{n-1} \\
{\left[\mathrm{PLN} / \mathrm{m}^{2}\right]}\end{array}$} & \multirow[b]{2}{*}{$n$} & \multicolumn{2}{|c|}{ Linear model } & \multicolumn{2}{|c|}{ Non-linear model } \\
\hline & & & & & & $R^{2}$ & $\begin{array}{l}\text { Relevant } \\
\text { model } \\
\text { variables }\end{array}$ & $R^{2}$ & $\begin{array}{c}\text { Relevant } \\
\text { model } \\
\text { variables }\end{array}$ \\
\hline 1 & Starachowice & 5 & 39.44 & 38.11 & 65 & 0.77 & $\begin{array}{l}\text { surrounding, } \\
\text { utilities }\end{array}$ & 0.82 & $\begin{array}{c}\text { topography, } \\
\text { road type, } \\
\text { surrounding, } \\
\text { utilities }\end{array}$ \\
\hline 2 & Busko - Zdrój & 7 & 33.49 & 11.53 & 32 & 0.96 & $\begin{array}{c}\text { location, land } \\
\text { area, } \\
\text { accessibility } \\
\text { to public } \\
\text { facilities, } \\
\text { shape, } \\
\text { fashion }\end{array}$ & 0.88 & $\begin{array}{c}\text { area, } \\
\text { accessibility to } \\
\text { public } \\
\text { facilities, } \\
\text { shape, } \\
\text { fashion, } \\
\text { surroundings }\end{array}$ \\
\hline 3 & Przeworsk & 7 & 16.42 & 3.02 & 35 & 0.81 & $\begin{array}{l}\text { shape, } \\
\text { fashion }\end{array}$ & 0.85 & $\begin{array}{c}\text { land area, } \\
\text { accessibility to } \\
\text { public facilities, } \\
\text { shape, } \\
\text { fashion }\end{array}$ \\
\hline 4 & Proszowice & 7 & 12.18 & 14.90 & 63 & 0.87 & $\begin{array}{c}\text { location, } \\
\text { shape, } \\
\text { accessibility to } \\
\text { public } \\
\text { facilities } \\
\end{array}$ & 0.83 & $\begin{array}{c}\text { shape, utilities, } \\
\text { location, }\end{array}$ \\
\hline 5 & $\begin{array}{l}\text { Kraków } \\
\text { Krowodrza }\end{array}$ & 3 & 178.93 & 94.98 & 30 & 0.86 & $\begin{array}{c}\text { location, } \\
\text { shape, } \\
\text { fashion }\end{array}$ & 0.61 & $\begin{array}{c}\text { accessibility to } \\
\text { public facilities, } \\
\text { shape, } \\
\text { fashion }\end{array}$ \\
\hline
\end{tabular}

Source: own study.

Functional models, both linear and non-linear, adjusted to the data on properties sold in Starachowice, Busko-Zdrój, Przeworsk and Proszowice achieved a high value of the determination coefficient $R^{2}$. Relatively low quality of fit of the non-linear model was obtained for Kraków, although $R^{2}$ was 0.86 in the linear model. In both functional models, not only the same explanatory variables were significant; most often, in non-linear models, a greater number was recorded, which can be seen on the example of data sets from Starachowice, Busko-Zdrój, Przeworsk and Kraków.

Table 1b

Basic numerical characteristics of significant independent variables in functional models

\begin{tabular}{|c|c|c|c|c|}
\hline Town & Attribute & $\hat{X}$ & $\sigma_{n-1}$ & $f_{i}(\mathrm{X})$ \\
\hline \multirow{4}{*}{ Starachowice } & surroundings & 3.9 & 1.0 & $a_{1}{ }^{*}$ surroundings \\
\hline & utilities & 0.6 & 1.4 & $a_{2}{ }^{*}$ utilities \\
\hline & topography & 4.6 & 0.8 & $a_{3}{ }^{*}(\text { topography })^{2}+a_{4} *$ topography \\
\hline & road type & 4.2 & 1.4 & $a_{5}{ }^{*}(\text { road type })^{2}+a_{6}{ }^{*}$ road type \\
\hline \multirow{2}{*}{ Busko - Zdrój } & location & 2.6 & 0.6 & $a_{1}^{*}$ location \\
\hline & land area & 1088.4 & 708.6 & $a_{2}{ }^{*}$ land area \\
\hline
\end{tabular}




\section{S sciendo}

\begin{tabular}{|c|c|c|c|c|}
\hline & $\begin{array}{l}\text { accessibility to } \\
\text { public facilities }\end{array}$ & 1.6 & 0.8 & $a_{3}{ }^{*}$ accessibility to public facilities \\
\hline & shape & 1.5 & 0.9 & $a_{4}^{*}$ shape \\
\hline & fashion & 2.3 & 1.5 & $a_{5}{ }^{*}$ fashion \\
\hline & surroundings & 1.5 & 0.8 & $\begin{array}{l}a_{6}{ }^{*}(\text { surroundings })^{3}+a_{7}{ }^{*}(\text { surroundings })^{2+} a_{8}{ }^{*} \\
\text { surroundings }\end{array}$ \\
\hline \multirow{4}{*}{ Przeworsk } & shape & 1.0 & 0.7 & $a_{1}^{*}$ shape \\
\hline & fashion & 1.5 & 0.7 & $a_{2}{ }^{*}$ fashion \\
\hline & land area & 2170.9 & 1619.3 & $a_{3}{ }^{*}(\text { land area })^{3+} a_{4} *(\text { land area })^{2}+a_{5}^{*}$ land area \\
\hline & $\begin{array}{l}\text { accessibility to } \\
\text { public facilities }\end{array}$ & 1.4 & 0.6 & $\begin{array}{l}a_{6}^{*}(\text { accessibility to public facilities })^{2}+ \\
+a_{7}^{*} \text { accessibility to public facilities }\end{array}$ \\
\hline \multirow{4}{*}{ Proszowice } & location & 2.0 & 1.2 & $a_{1}^{*}$ location \\
\hline & shape & 1.0 & 0.5 & $a_{2}{ }^{*}$ shape \\
\hline & $\begin{array}{l}\text { accessibility to } \\
\text { public facilities }\end{array}$ & 1.0 & 0,9 & $a_{3}{ }^{*}$ accessibility to public facilities \\
\hline & utilities & 3.0 & 1,2 & $a_{4}{ }^{*}$ utilities ${ }^{2}+a_{4}{ }^{*}$ utilities \\
\hline \multirow{5}{*}{$\begin{array}{l}\text { Kraków } \\
\text { Krowodrza }\end{array}$} & location & 1.4 & 0,5 & $a_{1}^{*}$ location \\
\hline & shape & 1.5 & 0,6 & $a_{2}{ }^{*}$ shape \\
\hline & fashion & 3.7 & 1,0 & $a_{3}{ }^{*}$ fashion \\
\hline & land area & 2200.3 & 1705,0 & $a_{4}^{*}(\text { land area })^{2}+a_{5}^{*}$ land area \\
\hline & $\begin{array}{l}\text { accessibility to } \\
\text { public facilities }\end{array}$ & 1.6 & 0,8 & $\begin{array}{l}a_{6}{ }^{*}(\text { accessibility to public facilities })^{2+} \\
+a_{7}^{*} \text { accessibility to public facilities }\end{array}$ \\
\hline
\end{tabular}

Source: own study.

Tables 2 and 3 contain: results of obtained model values of appraised properties $W$ with standard deviations of these values $\sigma(W), o$ - number of outliers, $R^{2}{ }_{0}$ - value of corrected determination coefficient due to the number of freedom degrees after removing outliers, detected by Cook's distance (OC) and Pope's method (MP), $R^{2}{ }_{0}-R^{2}$ - difference between the value of determination coefficient of functional model, after and before removal of outliers, $C_{\text {trans }}$ - transaction prices obtained for the real estate being the subject of valuation and the share of the standard deviation of the model value estimator in this model value (coefficient of variability of the model value) as well as the result of the interval estimation for the estimated value at the confidence level of $p=0.95$. The yellow color marks those markets where the transaction price of the sold real estate was in the confidence interval at the assumed level of $p=0.95$. It should be noted that, in the case of Busko-Zdrój, the transaction price is very close to the confidence limit obtained after applying the linear model. Probably a slight increase in the $p$ level would make this price fall into the range.

Table 2

Summary of the obtained results for the linear model

\begin{tabular}{|c|c|c|c|c|c|c|c|c|c|}
\hline Town & Method & $o$ & $R^{2}{ }_{\mathrm{o}}$ & $R^{2} \mathrm{o}-R^{2}$ & $\begin{array}{c}\begin{array}{c}C_{\text {trans }} \\
{\left[\mathrm{PLN} / \mathrm{m}^{2}\right]}\end{array} \\
\end{array}$ & $\begin{array}{c}W \\
\left.\mathrm{PLN} / \mathrm{m}^{2}\right] \\
\end{array}$ & $\begin{array}{c}\sigma(W) \\
{\left[\mathrm{PLN} / \mathrm{m}^{2}\right]}\end{array}$ & $\begin{array}{c}W \pm z(0,975)^{*} \sigma(W) \\
{\left[\mathrm{PLN} / \mathrm{m}^{2}\right]}\end{array}$ & $\frac{\sigma(W)}{W}$ \\
\hline \multirow{2}{*}{ Starachowice } & OC & 5 & 0.84 & 0.07 & \multirow{2}{*}{12.89} & 15.37 & 2.38 & {$[10.71 ; 20.03]$} & 0.15 \\
\hline & MP & 19 & 0.92 & 0.15 & & 11.07 & 1.14 & {$[8.84 ; 13,30]$} & 0.10 \\
\hline \multirow{2}{*}{ Busko - Zdrój } & $\mathrm{OC}$ & 1 & 0.97 & 0.01 & \multirow{2}{*}{18.29} & 19.48 & 0.58 & [18.34;20.61] & 0.0 \\
\hline & $\mathrm{MP}$ & 3 & 0.98 & 0.02 & & 19.52 & 0.56 & [18.42;20.62] & 0.03 \\
\hline \multirow{2}{*}{ Przeworsk } & OC & 2 & 0.77 & -0.04 & \multirow{2}{*}{15.00} & 14.85 & 0.48 & [13.91;15.79] & 0.03 \\
\hline & MP & 3 & 0.89 & 0.08 & & 15.15 & 0.19 & [14.78;15.52] & 0.01 \\
\hline \multirow{2}{*}{ Proszowice } & OC & 3 & 0.93 & 0.06 & \multirow{2}{*}{28.52} & 38.45 & 1.06 & {$[36.37 ; 40.53]$} & 0.03 \\
\hline & MP & 9 & 0.96 & 0.09 & & 37.99 & 0.92 & [36.19;39.79] & 0.02 \\
\hline \multirow{2}{*}{$\begin{array}{c}\text { Kraków } \\
\text { Krowodrza }\end{array}$} & $\mathrm{OC}$ & 1 & 0.91 & 0.05 & \multirow{2}{*}{80.00} & 73.00 & 10.22 & [52.97;93.03] & 0.14 \\
\hline & MP & 5 & 0.95 & 0.09 & & 76.78 & 7.71 & [61.67;91.89] & 0.10 \\
\hline
\end{tabular}

Source: own study.

Each of the methods of detecting outliers from the linear model matched the data set, but Pope's 
method pointed to more atypical cases each time, which caused a higher increase of the determination coefficient value. The variability coefficient of estimated model value did not exceed $15 \%$. In the database for Przeworsk, after applying Cook's distance, a deterioration in the quality of fitting the functional model to the data was noted. Nevertheless, due to a decrease of the value of the standard estimation error, and thus an increase in the accuracy of the performed estimation, it was decided to consider the linear model to determine the model value for real estate in this real estate market.

Summary of the obtained results for the non-linear model

Table 3

\begin{tabular}{|c|c|c|c|c|c|c|c|c|c|}
\hline Town & Method. & $o$ & $R^{2}{ }_{\mathrm{o}}$ & $R^{2}{ }_{\mathrm{o}}-R^{2}$ & $\begin{array}{c}C_{\text {trans }} \\
{\left[\mathrm{PLN} / \mathrm{m}^{2}\right]}\end{array}$ & $\begin{array}{c}W \\
{\left[\mathrm{PLN} / \mathrm{m}^{2}\right]}\end{array}$ & $\begin{array}{c}\sigma(W) \\
{\left[\mathrm{PLN} / \mathrm{m}^{2}\right]}\end{array}$ & $\begin{array}{c}W \pm z(0.975)^{*} \sigma(W) \\
{\left[P L N / m^{2}\right]}\end{array}$ & $\frac{\sigma(W)}{W}$ \\
\hline \multirow{2}{*}{ Starachowice } & OC & 3 & 0.85 & 0.03 & \multirow{2}{*}{12.89} & 13.99 & 4.85 & {$[4.48 ; 23.50]$} & 0.35 \\
\hline & MP & 5 & 0.90 & 0.08 & & 10.45 & 4.49 & {$[1.65 ; 19.25]$} & 0.43 \\
\hline \multirow{2}{*}{ Busko - Zdrój } & OC & 5 & 0.94 & 0.06 & \multirow{2}{*}{$18 . .29$} & $17 . .41$ & $1 . .93$ & [13.63;21.19] & 0.11 \\
\hline & MP & 0 & 0.88 & 0.00 & & 18.27 & 0.56 & [17.17;19.37] & 0.03 \\
\hline \multirow{2}{*}{ Przeworsk } & $\mathrm{OC}$ & 2 & 0.88 & 0.03 & \multirow{2}{*}{15.00} & 15.28 & 0.52 & {$[14.26 ; 16.30]$} & 0.03 \\
\hline & $\mathrm{MP}$ & 2 & 0.92 & 0.07 & & 15.28 & 0.51 & {$[14.28 ; 16.28]$} & 0.03 \\
\hline \multirow{2}{*}{ Proszowice } & OC & 4 & 0.90 & 0.07 & \multirow{2}{*}{28.52} & 27.89 & 1.82 & {$[24.32 ; 31.46]$} & 0.07 \\
\hline & $\mathrm{MP}$ & 3 & 0.90 & 0.07 & & 26.32 & 1.69 & {$[23.01 ; 29.63]$} & 0.06 \\
\hline \multirow{2}{*}{$\begin{array}{c}\text { Kraków } \\
\text { Krowodrza }\end{array}$} & OC & 4 & 0.67 & 0.06 & \multirow{2}{*}{80.00} & 79.93 & 16.45 & [47.69;112.17] & 0.21 \\
\hline & MP & 2 & 0.77 & 0.16 & & 78.69 & 14.31 & {$[51.88 ; 107.98]$} & 0.18 \\
\hline
\end{tabular}

Source: own study.

As can be seen in Table 3, Pope's method and Cook's distance detected similar numbers of outliers. In every data set, there was the increase in the quality of fit of the non-linear model to data after removal of outliers, reaching even $16 \%$ in the case of the Cracovian market. An exception is the database for Busko-Zdrój, where MP did not point to atypical observations. Prices of properties sold in Starachowice, Busko - Zdrój, Przeworsk, Proszowice and Kraków are contained in the confidence intervals for model values of these parcels, calculated on $p$-level $=0.95$ and the variability coefficient of estimated model value, despite growingsignificantly in relation to its equivalent from the linear model, did not exceed $43 \%$.

Tables 4 and 5 present the comparison results of:

- model values of valuated properties with transaction prices, which were noted for them, by using the test of single average value, at the significance level $a=0.05$. According to number of observations in analyzed data sets, which is equal to $n-0$, test statistics from normal distribution $Z$ or $t$-Student distribution $T$ were calculated;

- model values of the valuated property, obtained with the same model after removing outliers, detected by Pope's method and Cook's distance, by a test which verifies two average values, at the significance level $a=0.05$. According to number of observations in analyzed data sets, which is equal to $n-0$, test statistics from normal distribution $Z$ or $t$-Student distribution $T$ or so called Cochran-Cox statistics $C$ were calculated; Cochran-Cox's distribution is expressed by $t$-Student distribution;

- standard deviations of model values of valuated properties $\sigma(W)$, with application of $F$ test, at the significance level $a=0.05$.

The values of the test functions are highlighted in red, which indicates the necessity to reject the zero hypothesis of equality of, in this case, the standard deviations of the model values $\sigma(W)$ and the model value $W$ and the transaction price $C_{\text {trans }}$.

Based on the performed parametric significance tests (Table 4), it is established that:

- model values of valuated properties sold in Busko-Zdrój and Proszowice differ substantially from their transactions prices, at the significance level $a=0.05$,

- despite a different number of observations considered as outliers selected by OC and MP, the model values of the appraised real estate are statistically the same,

- the estimators of the standard deviation of the model values obtained after removing the outliers detected by OC differ significantly from the estimators of the standard deviation of the model values obtained after using MP in the data sets for Starachowice and Przeworsk, in favor of Pope's algorithm. 
Comparison of the results from Table 2 (linear model)

\begin{tabular}{|c|c|c|c|c|c|c|c|c|}
\hline \multirow{2}{*}{$\sum_{\substack{0 \\
\qquad}}^{5}$} & \multirow{2}{*}{ 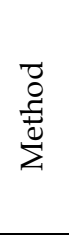 } & \multirow[b]{2}{*}{$n-o$} & \multicolumn{2}{|c|}{$\begin{array}{l}\text { Test comparing } \\
\text { the } W \text { and } C_{\text {trans }} \text { values }\end{array}$} & \multicolumn{2}{|c|}{$\begin{array}{c}\text { Test comparing } \\
\text { the } W \text { values }\end{array}$} & \multicolumn{2}{|c|}{$\begin{array}{l}\text { Test comparing } \\
\text { the } \sigma(W) \text { values }\end{array}$} \\
\hline & & & $\begin{array}{c}\text { Test } \\
\text { function }\end{array}$ & $\begin{array}{c}\text { Critical area } \\
\quad a=0.05\end{array}$ & $\begin{array}{c}\text { Test } \\
\text { function }\end{array}$ & $\begin{array}{c}\text { Critical area } \\
\quad \cdot \quad \\
a=0.05\end{array}$ & $F$ & $\begin{array}{c}\text { Critical } \\
\text { area } \\
a=0.05\end{array}$ \\
\hline \multirow{2}{*}{ S-ce } & OC & 60 & $Z=1.0420$ & $(-\infty ;-1.9600)$ & \multirow{2}{*}{$Z=1.6294$} & $(-\infty ;-1.9600)$ & \multirow{2}{*}{3.28} & \multirow{2}{*}{$(1.62 ;+\infty)$} \\
\hline & MP & 46 & $Z=-1.5965$ & $(1.9600 ;+\infty)$ & & $(1.9600 ;+\infty)$ & & \\
\hline \multirow{3}{*}{ B-Z } & & & & $(-\infty ;-1.9600)$ & \multirow{3}{*}{$T=-0.2714$} & \multirow{3}{*}{$\begin{array}{c}(-\infty ;-2.0106) \\
\cup \\
(2.0106 ;+\infty)\end{array}$} & \multirow{3}{*}{1.01} & \multirow{3}{*}{$(2.00 ;+\infty)$} \\
\hline & OC & 31 & $Z=2.0517$ & $\begin{array}{c}U \\
(1.9600 ;+\infty)\end{array}$ & & & & \\
\hline & MP & 29 & $T=2.1965$ & $\begin{array}{c}(-\infty ;-2.0687) \\
\cup \\
(2.0687 ;+\infty) \\
\end{array}$ & & & & \\
\hline \multirow{2}{*}{ P-k } & OC & 33 & $Z=-0.3125$ & $(-\infty ;-1.9600)$ & \multirow{2}{*}{$Z=-0.5811$} & $(-\infty ;-1.9600)$ & \multirow{2}{*}{6.17} & \multirow{2}{*}{$(1.85 ;+\infty)$} \\
\hline & MP & 32 & $Z=0.7895$ & $(1.9600 ;+\infty)$ & & $(1.9600 ;+\infty)$ & & \\
\hline \multirow[b]{2}{*}{ P-ce } & OC & 60 & $Z=9.3679$ & $(-\infty ;-1.9600)$ & \multirow[b]{2}{*}{$Z=0.3277$} & \multirow{2}{*}{$\begin{array}{c}(-\infty ;-1.9600) \\
\cup \\
(1.9600 ;+\infty)\end{array}$} & \multirow[b]{2}{*}{1.19} & \multirow[b]{2}{*}{$(1.58 ;+\infty)$} \\
\hline & MP & 54 & $Z=10.2935$ & $\underset{(1.9600 ;+\infty)}{U}$ & & & & \\
\hline \multirow{3}{*}{ K-ów } & & & & $(-\infty ;-2.0595)$ & \multirow{3}{*}{$T=-0.2648$} & \multirow{3}{*}{$\begin{array}{c}(-\infty ;-2.0129) \\
\cup \\
(2.0129 ;+\infty)\end{array}$} & \multirow{3}{*}{1.48} & \multirow{3}{*}{$(2,05 ;+\infty)$} \\
\hline & OC & 29 & $T=-0.6849$ & $\frac{U}{(2.0595 ;+\infty)}$ & & & & \\
\hline & MP & 25 & $T=-0.4176$ & $\begin{array}{c}(-\infty ;-2.0796) \\
U \\
(2.0796 ;+\infty)\end{array}$ & & & & \\
\hline
\end{tabular}

Source: own study.

Results presented in Table 5 indicate that:

- model values of the real estate appraised do not differ significantly from their transaction prices, at the significance level of $a=0.05$,

- model values obtained after applying OC and MP are statistically the same, despite the different number of outliers selected by the discussed methods,

- the estimator of the standard deviation of the model value, obtained after removing the outliers, detected by the OC differs significantly from the estimator of the standard deviation of the model value obtained using the MP in the transaction database for Busko-Zdrój, in favor of Pope's method.

Table 5

Comparison of the results from Table 3 (non-linear model)

\begin{tabular}{|c|c|c|c|c|c|c|c|c|}
\hline \multirow{2}{*}{ 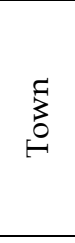 } & \multirow{2}{*}{ 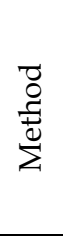 } & \multirow[b]{2}{*}{$n-o$} & \multicolumn{2}{|c|}{$\begin{array}{l}\text { Test comparing } \\
\text { the } W \text { and } C_{\text {trans }} \text { values }\end{array}$} & \multicolumn{2}{|c|}{$\begin{array}{l}\text { Test comparing } \\
\text { the } W \text { values }\end{array}$} & \multicolumn{2}{|c|}{$\begin{array}{l}\text { Test comparing } \\
\text { the } \sigma(W) \text { values }\end{array}$} \\
\hline & & & $\begin{array}{c}\text { Test } \\
\text { function }\end{array}$ & $\begin{array}{c}\text { Critical area } \\
a=0.05\end{array}$ & $\begin{array}{c}\text { Test } \\
\text { function }\end{array}$ & $\begin{array}{c}\text { Critical area } \\
\quad a=0.05\end{array}$ & $F$ & $\begin{array}{c}\text { obszar } \\
\text { kryt. } \\
a=0.05\end{array}$ \\
\hline \multirow[b]{2}{*}{ S-ce } & OC & 62 & $Z=0.2268$ & \multirow{2}{*}{$\begin{array}{c}(-\infty ;-1.9600) \\
\cup \\
(1.9600 ;+\infty)\end{array}$} & \multirow[b]{2}{*}{$Z=0.5356$} & $(-\infty ;-1.9600)$ & \multirow[b]{2}{*}{1.13} & \multirow[b]{2}{*}{$(1.56 ;+\infty)$} \\
\hline & MP & 60 & $Z=-0.5434$ & & & $\begin{array}{c}U \\
(1.9600 ;+\infty)\end{array}$ & & \\
\hline B-Z & OC & 27 & $T=-0.4560$ & $\begin{array}{c}(-\infty ;-2.0796) \\
U\end{array}$ & $C=-0.4279$ & $\begin{array}{c}(-\infty ;-2.0780) \\
\cup\end{array}$ & 14.71 & $(1.98 ;+\infty)$ \\
\hline
\end{tabular}




\begin{tabular}{|c|c|c|c|c|c|c|c|c|}
\hline & & \multirow[b]{2}{*}{32} & \multirow[b]{2}{*}{$Z=-0.0357$} & \multirow{2}{*}{$\begin{array}{c}(2.0796 ;+\infty) \\
(-\infty ;-1.9600) \\
\cup \\
(1.9600 ;+\infty)\end{array}$} & \multirow[t]{2}{*}{ 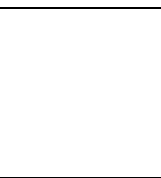 } & \multirow[t]{2}{*}{$(2.0780 ;+\infty)$} & & \\
\hline & MP & & & & & & & \\
\hline \multirow{2}{*}{ P-k } & OC & 33 & $Z=0.5385$ & \multirow{2}{*}{$\begin{array}{c}(-\infty ;-1.9600) \\
\cup \\
(1.9600 ;+\infty)\end{array}$} & \multirow{2}{*}{$Z=0.0000$} & \multirow{2}{*}{-} & \multirow{2}{*}{1.04} & \multirow{2}{*}{$(1.88 ;+\infty)$} \\
\hline & MP & 33 & $Z=0.5490$ & & & & & \\
\hline \multirow[b]{2}{*}{ P-ce } & OC & 59 & $Z=-0.3462$ & \multirow{2}{*}{$\begin{array}{c}(-\infty ;-1.9600) \\
\cup \\
(1.9600 ;+\infty)\end{array}$} & \multirow[b]{2}{*}{$Z=0.6321$} & \multirow{2}{*}{$\begin{array}{c}(-\infty ;-1.9600) \\
\cup \\
(1.9600 ;+\infty)\end{array}$} & \multirow[b]{2}{*}{1.18} & \multirow[b]{2}{*}{$(1.56 ;+\infty)$} \\
\hline & MP & 60 & $7=-13018$ & & & & & \\
\hline \multirow{3}{*}{ K-ów } & & & & $(-\infty ;-2.0796)$ & \multirow{3}{*}{$T=0.2967$} & \multirow{3}{*}{$\begin{array}{c}(-\infty ;-2.0154 \\
\cup \\
2.0154 ;+\infty)\end{array}$} & \multirow{3}{*}{1.21} & \multirow{3}{*}{$(2.06 ;+\infty)$} \\
\hline & OC & 26 & $T=-0.0042$ & $\begin{array}{c}U \\
(2.0796 ;+\infty)\end{array}$ & & & & \\
\hline & MP & 28 & $T=-0.0915$ & $\begin{array}{c}(-\infty ;-2,0687) \\
\cup \\
(2.0687 ;+\infty)\end{array}$ & & & & \\
\hline
\end{tabular}

Source: own study.

\section{Summary and conclusions}

The considerations about the application of chosen statistical methods for finding outliers in the property valuation procedure lead to the following conclusions:

- model values obtained on the basis of the estimation of parameters of non-linear models give a greater chance of approaching the transaction price, as evidenced by the Busko-Zdrój case, where the transaction price is within the specified confidence interval, as opposed to the result obtained for the linear model. Moreover, the conducted statistical tests did not show a significant difference between the model value of the property valued, determined on the basis of the non-linear model, and its transaction price, as opposed to the model value obtained from the linear model,

- both Cook's distance and Pope's method work similarly in the context of approximating the model value to the transaction price, regardless of the type of functional model, as indicated by the results of the interval estimation - for most markets (except Busko-Zdrój and Proszowice) the transaction price is found within the confidence interval,

- in the context of improving the quality of fitting the functional model to the data set, Pope's method gives better absolute results, i.e. a greater value of the difference between the value of the determination coefficient of the functional model after and before removing outliers,

- in the case of linear models, Pope's method is more restrictive because it rejects a larger number of observations,

- in the case of non-linear models, the number of outliers selected using both methods is at a similar level (Busko-Zdrój is an exception, where Pope's method did not find outliers),

- statistical tests did not indicate significant differences between the obtained values of $W$ at the significance level $a=0.05$, which may mean that despite different algorithms, the discussed methods give similar results in the context of the obtained values of real estate appraisal,

- where the parametric significance test showed a significant difference between the accuracy of the estimated model values - it was always in favor of Pope's method; this may be a reason to consider this method as leading to more accurate results of forecasting the model real estate value.

\section{Literature}

Barańska, A. (2007). Two-Stage Model for Estimating Real Estates. Real Estate Management and Valuation, 15(3-4), 187-196.

Barańska, A. (2008) Criteria of using of stochastic models in prediction of real estate market value, Application of statistical methods in scientific research, Statsoft, online access https://media.statsoft.pl/_old_dnn/downloads/kryteria_stosowania_modeli.pdf 


\section{S sciendo}

Barańska, A. (2010). Multiplicative models in real estate assessment process. Real Estate Management and Valuation, 18(1), 65-81.

Barańska, A., \& Michalik, S. (2014). Variants of modeling dwelling market value. Real Estate Management and Valuation, 22(3), 28-35. https://doi.org/10.2478/remav-2014-0024

Barańska, A., Nowak, D. (2015). Function modelling of the market and assessing the degree of similarity between real properties - dependent or independent procedures in the process of office property valuation, Real Estate Management and Valuation, 23(3).

Barańska, A. (2016). The significance of database in modelling the market of non - residential premises. Real Estate Management and Valuation, 24(2), 47-56. https://doi.org/10.1515/remav-2016$\underline{0013}$

Barros, M., Galea, M., Gonzáles, M., \& Leiva, V. (2010). Influence diagnostics in the tobit censored response model. Statistical Methods \& Applications, 19(3), 379-397. https://doi.org/10.1007/s10260010-0135-y

Cook R., Weisberg S., 1982. Residuals and Influence in Regression. Chapman\&Hall, Nowy Jork.

Pope, A. J. (1976), The statistics of residuals and the detection of outliers. NOAA Technical Report. NOS 65 NGS 1, U.S. Dept. of Commerce, Rockville, Md., 1976.

Czaja, J., \& Ligas, M. (2010). Advanced statistical analysis for real estate market research. Real Estate Management and Valuation, 18(1), 7-19.

Czekaj, T. (2006). Outliers and Influential Observations in Regression Analysis - Analysis of Profitability of Material Factors of Production in Farms. Annals of the Polish Association of Agricultural and Agribusiness Economists, (5), 11-15.

Czechowski, P., Badyda, A., \& Majewski, G. (2013). Data Mining System For Air Quality Monitoring Networks. Archives of Environmental Protection, 39(4), 123-147. Advance online publication. https://doi.org/10.2478/aep-2013-0041

Hildago, J. A., Perez Suay, A., Nar, F., \& Campus-Valls, G. (2018). Nonlinear Cook Distance for Anomalous Change Detection, Conference Paper, International Geoscience and Remote Sensing Symposium (IGARSS), Valencia 2018.

Hormann, S., Pfeiler, B., \& Stadlober, E. (2005). Analysis and Prediction of Particulate Matter PM10 for the Winter Season in Graz. The Australian Journal of Statistics, 34(4), 307-326.

Kamiński, W., \& Nowel, K. (1992). Analysis of Chosen Robust Methods of Geodetic Observation Adjustment. Geodesy and Cartography, 3-4(41), 183-195.

Kokot, S. (2011). A statistical method for market analysis in theory and practice real estate valuation : Introduction to discussion on the future professional standards. [Przegląd geodezyjny]. Survey Review, 83(3), 3-8.

Kokot, S., \& Gnat, S. (2019). Simulative verification of the possibility of using multiple regression models for the real estate appraisal. Real Estate Management and Valuation, 27(3), 109-123. https://doi.org/10.2478/remav-2019-0029

Konowalczuk J. (2018). Comparison in Statistical Market Analysis Method Used for Real Estate Valuation in Poland, Cracow Review of Economics and Management, issue 3(975), pp. 125-143.

Koronacki, J., \& Mielniczuk, J. (2001). Statistics for Student of Technical and Natural Sciences. Scientific and Publishing House.

Prószyński, W., \& Kwaśniak, M. (2002). Reliability of Geodetic Networks. Warsaw Polytechnic Publishing House.

Sawiłow, E. (2010). The Problems of Qualifying the Value of Real Estate with the Method of the Statistical Analysis of the Market. Real Estate Management and Valuation, 18(1), 21-31.

Śpiewak B. (2018). Application of Passive Methods of Robust Estimation: Baarda and Pope's in Real Estate Market Analysis. Real Estate Management and Valuation, 26(1), 05-15.

Trzęsiok J. (2015). Robustness for Outliers of Selected Nonparametric Regression Models, Economic Studies. Scientific Journals of the University of Economics in Katowice [Studia Ekonomiczne. Zeszyty Naukowe Uniwersytetu Ekonomicznego w Katowicach]. No.27, pp. 75-84.

Zyga, J. 2014, Practical assessment of the admissibility of using the method of statistical analysis of the market in the valuation of real estate [Praktyczna ocena dopuszczalności zastosowania metody analizy statystycznej rynku w wycenie nieruchomości], Market analysis and property management, scientific monograph [Analiza rynku i zarządzanie nieruchomościami, monografia naukowa], Polish Real Estate Scientific Society, Olsztyn. p. 41-57. 
Zhao, J., Leng, C., Li, L., \& Wang, H. (2013). High - Dimensional Influence Measure. Annals of Statistics, 41(5), 2639-2667. https://doi.org/10.1214/13-AOS1165

Zhu, H., Ibrahim, J. G., \& Cho, H. (2012). Perturbation and Scaled Cook's Distance. Annals of Statistics, 40(2), 785-811. https:// doi.org/10.1214/12-AOS978 PMID:23152646 